\title{
Atmospheric chemistry of carboxylic acids: microbial implication versus photochemistry
}

\author{
M. Vaïtilingom ${ }^{1,2,3,4}$, T. Charbouillot ${ }^{3,4,5,6}$, L. Deguillaume ${ }^{3,4}$, R. Maisonobe ${ }^{1,2}$, M. Parazols ${ }^{1,2,5,6}$, P. Amato ${ }^{1,2}$, \\ M. Sancelme ${ }^{1,2}$, and A.-M. Delort ${ }^{1,2}$ \\ ${ }^{1}$ Clermont Université, Université Blaise Pascal, Laboratoire de Synthèse Et Etude de Systèmes à Intérêt Biologique, \\ BP 10448, 63000 Clermont-Ferrand, France \\ ${ }^{2}$ CNRS, UMR6504, 63177 Aubière, France \\ ${ }^{3}$ Clermont Université, Université Blaise Pascal, OPGC, Laboratoire de Météorologie Physique (LaMP), BP 10448, \\ 63000 Clermont-Ferrand, France \\ ${ }^{4}$ CNRS, UMR6016, 63177 Aubière, France \\ ${ }^{5}$ Clermont Université, Université Blaise Pascal, Laboratoire de Photochimie Moléculaire et Macromoléculaire (LPMM), \\ BP 10448, 63000 Clermont-Ferrand, France \\ ${ }^{6}$ CNRS, UMR6505, 63177 Aubière, France
}

Received: 29 November 2010 - Published in Atmos. Chem. Phys. Discuss.: 9 February 2011

Revised: 5 August 2011 - Accepted: 8 August 2011 - Published: 25 August 2011

\begin{abstract}
The objective of this work was to compare experimentally the contribution of photochemistry vs. microbial activity to the degradation of carboxylic acids present in cloud water. For this, we selected 17 strains representative of the microflora existing in real clouds and worked on two distinct artificial cloud media that reproduce marine and continental cloud chemical composition. Photodegradation experiments with hydrogen peroxide $\left(\mathrm{H}_{2} \mathrm{O}_{2}\right)$ as a source of hydroxyl radicals were performed under the same microcosm conditions using two irradiation systems. Biodegradation and photodegradation rates of acetate, formate, oxalate and succinate were measured on both media at $5{ }^{\circ} \mathrm{C}$ and $17^{\circ} \mathrm{C}$ and were shown to be on the same order of magnitude (around $10^{-10}-10^{-11} \mathrm{M} \mathrm{s}^{-1}$ ). The chemical composition (marine or continental origin) had little influence on photodegradation and biodegradation rates while the temperature shift from $17^{\circ} \mathrm{C}$ to $5^{\circ} \mathrm{C}$ decreased biodegradation rates of a factor 2 to 5 .

In order to test other photochemical scenarios, theoretical photodegradation rates were calculated considering hydroxyl $(\mathrm{OH})$ radical concentration values in cloud water estimated by cloud chemistry modelling studies and available reaction rate constants of carboxylic compounds with both hydroxyl and nitrate radicals. Considering high $\mathrm{OH}$ concentration $\left([\mathrm{OH}]=1 \times 10^{-12} \mathrm{M}\right)$ led to no significant contri-
\end{abstract}

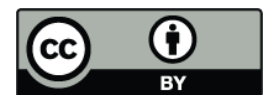

Correspondence to: M. Vaïtilingom (mickael.vaitilingom@univ-bpclermont.fr) bution of microbial activity in the destruction of carboxylic acids. On the contrary, for lower $\mathrm{OH}$ concentration (at noon, $\left.[\mathrm{OH}]=1 \times 10^{-14} \mathrm{M}\right)$, microorganisms could efficiently compete with photochemistry and in similar contributions than the ones estimated by our experimental approach.

Combining these two approaches (experimental and theoretical), our results led to the following conclusions: oxalate was only photodegraded; the photodegradation of formate was usually more efficient than its biodegradation; the biodegradation of acetate and succinate seemed to exceed their photodegradation.

\section{Introduction}

Clouds play a key role in the transformation of chemical species through exchanges between the gaseous and the aqueous phase and reactivity in each compartment (Jacob et al., 1986; Lelieveld and Crutzen, 1991; Ravishankara, 1997; Monod and Carlier, 1999). In cloud droplets the organic matter represents a significant fraction of the soluble matter (Hadi et al., 1995; Saxena and Hildemann, 1996; Fuzzi et al., 2002). Among the dissolved organic compounds, carboxylic acids are ubiquitous (Chebbi and Carlier, 1996; Löflund et al., 2002) and come from various sources. They are produced in the gas-phase and dissolved into the aqueous phase (main source of monocarboxylic acids such as acetic and formic acids) (Winiwarter et al., 1994; Laj et al., 1997); they can

Published by Copernicus Publications on behalf of the European Geosciences Union. 
also result from the dissolution of the soluble part of organic particles (source of dicarboxylic acids like oxalic, succinic, malonic and maleic acids ...) (Sempéré and Kawamura, 1994; Sellegri et al., 2003; Legrand et al., 2005); and they also mainly derive from the aqueous phase reactivity (Ervens et al., 2004; Carlton et al., 2007; Tan et al., 2010). The oxidation of organic matter due to the presence of free radicals such as $\mathrm{OH}$ can be considered as an important source of carboxylic acids in the aqueous phase, but also as one of their main sinks (Karpel Vel Leitner and Doré, 1997; Ervens et al., 2003b; Herrmann, 2003; Warneck, 2003; Herrmann et al., 2010; Sun et al., 2010).

The aqueous phase of clouds also contains insoluble biological material such as bacteria, fungal spores, pollens, plant debris, etc. (Matthias-Maser et al., 2000; Bauer et al., 2002; Jaenicke, 2005; Burrows et al., 2009). The study from Matthias-Maser and Jaenicke (1995) indicates that bioaerosols can represent up to $30 \%$ of the total number of insoluble aerosols in clouds. Viable microorganisms have been recovered from rain (Casareto et al., 1996), cloud and fog samples (Fuzzi et al., 1997; Amato et al., 2005, 2007b; Ahern et al., 2007). In clouds, concentration of bacteria range from $0.8 \times 10^{3}$ to $2.4 \times 10^{5}$ cells ml $^{-1}$ and for fungi and yeasts from $8.9 \times 10^{2}$ to $2.5 \times 10^{4}$ cells ml $^{-1}$ (Sattler et al., 2001; Amato et al., 2007c). The microbial strains isolated from the atmosphere were likely originating from vegetation, soil, aquatic environments (Amato et al., 2007b; Burrows et al., 2009), and most of these microorganisms were able to survive and develop under the specific conditions existing in cloud water (chemical composition, low temperature, UV exposure) (Sattler et al., 2001; Amato et al., 2007b). Possible $\mathrm{C}$-sources for microorganisms in atmospheric waters are carboxylic acids, aldehydes and alcohols (Herlihy et al., 1987; Fuzzi et al., 1997; Ariya et al., 2002; Amato et al., 2005, 2007a; Côté et al., 2008; Deguillaume et al., 2008; Delort et al., 2010). Biological activity could therefore influence the budget of the organic matter in cloud droplets.

To test this hypothesis, in previous works, our strategy was first to screen the ability of a large number of microbial strains (60) isolated from clouds to degrade organic compounds (formate, acetate, lactate (D \& L), succinate, formaldehyde and methanol) under optimal conditions $\left(27^{\circ} \mathrm{C}\right)$ (Amato et al., 2005, 2007a). We have shown that enzymes responsible for these transformations were present in these microorganisms. To go further, we studied the response of one single strain (Pseudomonas graminis) under more realistic atmospheric conditions (Vaïtilingom et al., 2010). We used a microcosm mimicking cloud chemical composition typical from continental influence at two different temperatures representative of warm clouds $\left(5^{\circ} \mathrm{C}\right.$ and $\left.17^{\circ} \mathrm{C}\right)$. Biodegradation rates of acetate, formate, succinate and oxalate were measured and compared to radical chemistry. For this, the reactions of these organic compounds with the two major free radicals $\mathrm{OH}$ and $\mathrm{NO}_{3}$ were considered. We calculated theoretical photodegradation rates from radical con- centrations simulated by cloud chemistry models (Ervens et al., 2003b; Herrmann, 2003). This comparison showed that microorganisms would dominate the degradation of certain organic compounds in clouds during the night.

The objective of this work was to generalize our conclusions previously obtained on a single strain. For this, we selected 17 strains representative of the microflora existing in clouds and worked on two distinct artificial cloud media that reproduce marine and continental cloud chemical composition. Biodegradation rates of acetate, formate, oxalate and succinate were measured for all the strains on both media at $5^{\circ} \mathrm{C}$ and $17^{\circ} \mathrm{C}$. The goal was to investigate the effect of environmental parameters on the biodegradation efficiency of microorganisms. Biodegradation rates in natural cloud water sampled at the puy de Dôme station (France) with its own endogenous microflora and chemical composition was also investigated. The objective was to compare artificial microcosm and natural clouds. In addition, photodegradation experiments with hydrogen peroxide $\left(\mathrm{H}_{2} \mathrm{O}_{2}\right)$ as a source of hydroxyl radicals were performed under the same microcosm conditions to compare directly photochemistry to biodegradation processes. This is the first report of such comparison using experimental data. In the discussion, theoretical calculations based on various scenarios of the $\mathrm{OH}$ reactivity are presented.

\section{Material and methods}

\subsection{Bacterial strains}

Seventeen bacterial strains isolated from cloud water were selected; they are among the microbial genera that are most frequently recovered by culture from cloud water sampled at the puy de Dôme station (1465 ma.s.1) between December 2003 and March 2009 (see Amato et al., 2007c). The strains used are: 2 Pseudomonas sp. strains PDD-6b-4 (DQ512766) and PDD-14b-10 (DQ512794), 3 Pseudomonas syringae strains PDD-13b-1 (DQ512737), PDD-12b-8 (DQ512783) and PDD-13b-2 (DQ512785), 1 Pseudomonas viridiflava strain PDD-14b-14 (DQ512797), 1 Pseudomonas graminis strain PDD-13b-3 (DQ512786), 3 Sphingomonas sp. strains PDD-3b-10 (DQ512744), PDD-14b-5 (DQ512789) and PDD-14b-6 (DQ512790), 2 Frigoribacterium sp. stains PDD-14b-13 (DQ512796) and PDD-30b-1 (HQ256816), 1 Rhodococcus sp. strain PDD-23b-5 (HQ256785), 1 Arthrobacter rhombi strain PDD-3b-7 (DQ512742), 1 Bacillus pumilus strain PDD-5b-1 (DQ512749) and 1 Bacillus sp. PDD-16b-1 (not available in GenBank), and 1 Clavibacter michiganensis strain PDD-25b-3 (HQ256805).

\subsection{Biodegradation tests}

Biodegradation experiments consisted of "marine" or "continental" artificial cloud water solutions inoculated with bacterial cells and incubated at $5^{\circ} \mathrm{C}$ and $17^{\circ} \mathrm{C}$ for $120 \mathrm{~h}$ under 
aerobic conditions. Incubation media consisted of "marine" and "continental" artificial cloud water solutions (see Table 1 for composition) made by diluting stock solutions in ultrapure water (resistivity $\geq 18.2 \mathrm{M} \Omega \mathrm{cm}^{-1}$ ). Stock solutions were prepared from the following products: acetic acid (Aldrich, $\geq 99.99 \%$ ), formic acid (Fluka, 98\%), oxalic acid (Fluka, $\geq 99 \%$ ), succinic acid (Fluka, $\geq 99 \%$ ), $\mathrm{MgCl}_{2}, 6 \mathrm{H}_{2} \mathrm{O}$ (Fluka, $\geq 99 \%$ ), $\mathrm{CaCl}_{2}, 2 \mathrm{H}_{2} \mathrm{O}$ (Aldrich, $99 \%$ ), $\mathrm{K}_{2} \mathrm{SO}_{4}$ (Fluka, $\geq 99 \%$ ), $\mathrm{NaCl}$ (Aldrich, 99.5\%), $\mathrm{NH}_{4} \mathrm{NO}_{3}$ (Fluka, $\geq 99.5 \%$ ), $\mathrm{NaOH}$ (Merck, $99 \%$ ) and $\mathrm{H}_{2} \mathrm{SO}_{4}$ (Acros Organics, $\geq 95 \%)$. The artificial cloud water solutions were sterilized by autoclave $\left(20 \mathrm{~min}\right.$ at $\left.121^{\circ} \mathrm{C}\right)$ and stored at $5^{\circ} \mathrm{C}$ for less than $24 \mathrm{~h}$. In the case of biodegradation experiments, in order to have a better stabilization of the chemical composition and $\mathrm{pH}$ after the sterilization process, the artificial cloud media were prepared 10 times more concentrated than indicated in Table 1. In previous work (Vaïtilingom et al., 2010), we showed that, at constant ratio "cell concentration/degraded chemical compound concentration" and in the range of concentrations investigated, biodegradation rates are independent of the absolute cell and chemical concentrations.

Artificial cloud water solutions were inoculated with bacterial cells from pure cultures grown aerobically at $17^{\circ} \mathrm{C}$ (200 rotations per minute (rpm)) in R2A broth (Reasoner and Geldreich, 1985). Cells were harvested by centrifugation $\left(4000 \times \mathrm{g}, 15 \mathrm{~min} ., 4^{\circ} \mathrm{C}\right)$ after $18 \mathrm{~h}$ of growth (exponential phase), rinsed once in $\mathrm{NaCl}$ solution ( $8 \mathrm{~g}$ per liter) and twice in the incubation medium and finally resuspended in the incubation medium. The concentrations of cells in the test media were adjusted to $10^{6}$ cells $\mathrm{ml}^{-1}$ ( $\sim 10$ times higher than the average bacterial concentration found in clouds sampled at the puy de Dôme station (Amato et al., 2007c) based on the turbidity of the culture (optical depth at $575 \mathrm{~nm}$ ). Serial dilutions of the suspension were plated $(0.1 \mathrm{ml})$ on R2A (solid medium in a petri dish) and incubated at $17^{\circ} \mathrm{C}$ for Colony Forming Unit ( $\mathrm{CFU}$ ) counts, that allowed to determine the bacterial concentrations of the incubated media. These microbial concentrations were used to normalize the biodegradation rates (biodegradation rates per cell expressed in mol cell $\left.^{-1} \mathrm{~s}^{-1}\right)$.

At defined time steps (every hour from 0 to $8 \mathrm{~h}$ and at times zero plus 24, 48, 72 and $120 \mathrm{~h}$ ), samples of $1 \mathrm{ml}$ were taken for analysis by ion chromatography and were pelleted $(12000 \times \mathrm{g}, 3 \mathrm{~min})$ to eliminated cells; the supernatants were kept frozen until analysis. No chemical modification was observed during the time of incubation in the reference flask (cloud water solution without microorganisms).

\subsection{Photodegradation tests}

For photodegradation experiments, artificial cloud water solutions were prepared as indicated in Table 1, supplemented with $20 \mu \mathrm{M}$ of hydrogen peroxide $\mathrm{H}_{2} \mathrm{O}_{2}$ (Fluka, 30\%) (less than $30 \mathrm{~min}$ before irradiation), and exposed to controlled lights under agitation. The maximal concentration of $\mathrm{H}_{2} \mathrm{O}_{2}$ measured in natural cloud water sampled at the puy de Dôme were in the same range $(\sim 19 \mu \mathrm{M})$ (Marinoni et al., 2011). $\mathrm{H}_{2} \mathrm{O}_{2}$ was added for generating hydroxyl radicals in the solutions by photolysis reaction $(\lambda<380 \mathrm{~nm})$.

Two irradiation setups, characterized by different polychromatic light spectra were used:

The Photochemical setup 1 (P1): consisted in a light beam generated by a $1000 \mathrm{~W}$ Xenon lamp used on the top of a cylindrical reactor equipped by a Pyrex filter (thickness $3.3 \mathrm{~mm}$, wavelength cut-off: $290 \mathrm{~nm}$ ) containing $500 \mathrm{ml}$ of magnetically stirred solution at $17^{\circ} \mathrm{C}$ (by circulating temperature-regulated water through an outer jacket).

The Photochemical setup 2 (P2): consisted in a box equipped by 12 Philips Actinic BL $15 \mathrm{~W}$ fluorescent tubes emitting within the wavelength range $340-420 \mathrm{~nm}$ with a maximum emission at $365 \mathrm{~nm}$ and placed above the incubation flasks. The incubation flasks were cylindrical Pyrex crystallizer $(100 \mathrm{ml})$ dishes covered with a Pyrex filter and incubated at $17^{\circ} \mathrm{C}$ under agitation (110 rpm).

The wavelength-dependent light fluxes reaching the solutions were measured by placing an optical fiber coupled to a spectrograph with a CCD detector (Ocean Optics SD 2000 CCD spectrophotometer) previously calibrated by using a DH-2000-CAL Deuterium Tungsten Halogen reference lamp inside a chemical reactor. Emission spectra of both photochemical setups and the UV-Vis spectra of nitrate and hydrogen peroxide in water solution are displayed in Fig. 1.

Effective degradation of hydrogen peroxide was verified in both setups by a fluorimetry assay involving a Horse Radish Peroxydase in 4-Hydroxyphenylacetic acid solution (Lazrus et al., 1985). At defined time points, two aliquots of $1 \mathrm{ml}$ of the solution incubated at $17^{\circ} \mathrm{C}$ (no experiment of photochemistry was made at $5^{\circ} \mathrm{C}$ due to technical limitations) were taken and kept frozen until ion chromatography analysis.

A control experiment was performed under irradiation without $\mathrm{H}_{2} \mathrm{O}_{2}$. No degradation was observed for all the organic compounds except for oxalate. This degradation was less than $5 \%$ over the whole incubation time and thus negligible as compared to this degradation in presence of $\mathrm{H}_{2} \mathrm{O}_{2}$.

\subsection{Natural cloud water sample collection and conditions of incubation}

Cloud water was collected at the puy de Dôme station using a sterilized cloud water sampler (Kruisz et al., 1993). The sampling method was identical to those described in Amato et al. (2005). The collection was performed on 17 June 2008, during a North-Western flow air mass and the average temperature over the time of sampling was $11^{\circ} \mathrm{C}$. 
Table 1. Chemical composition of the artificial cloud water media and of the natural cloud water sample used for incubation experiments, and range of values observed in natural cloud water collected at the puy de Dôme station.

\begin{tabular}{|c|c|c|c|c|c|}
\hline & \multicolumn{2}{|c|}{$\begin{array}{l}\text { Artificial cloud } \\
\text { water medium }\end{array}$} & \multirow[t]{2}{*}{$\begin{array}{l}\text { Natural cloud } \\
\text { water sample }\end{array}$} & \multicolumn{2}{|c|}{$\begin{array}{c}\text { Cloud water sampled at the } \\
\text { puy de Dôme station* }\end{array}$} \\
\hline & Marine & Continental & & $\min$ & $\max$ \\
\hline Compound & \multicolumn{5}{|c|}{ Concentration $(\mu \mathrm{M})$} \\
\hline Acetate & 20 & 20 & 24.3 & 0.6 & 48.7 \\
\hline Formate & 15 & 15 & 48.1 & 0.8 & 71.4 \\
\hline Succinate & 1.5 & 1.5 & 4.7 & 0.1 & 4.1 \\
\hline Oxalate & 3 & 3 & 9.8 & 0.1 & 17.4 \\
\hline $\mathrm{Cl}^{-}$ & 320 & 250 & 60.4 & 0.5 & 1948.9 \\
\hline $\mathrm{NO}_{3}^{-}$ & 70 & 200 & 192.1 & 3.4 & 766.8 \\
\hline $\mathrm{SO}_{4}^{2-}$ & 35 & 50 & 78.2 & 1.9 & 369.5 \\
\hline $\mathrm{Na}^{+}$ & 310 & 250 & 46.4 & 0.4 & 681.0 \\
\hline $\mathrm{NH}_{4}^{+}$ & 70 & 200 & 287.6 & 6.3 & 1801.7 \\
\hline $\mathrm{K}^{+}$ & 10 & 10 & 11.7 & 0.1 & 124.1 \\
\hline $\mathrm{Mg}^{2+}$ & 10 & 10 & 31.3 & 0.2 & 45.6 \\
\hline $\mathrm{Ca}^{2+}$ & 40 & 40 & 45.9 & 0.3 & 74.8 \\
\hline $\mathrm{pH}$ & $6-6.5$ & $4.7-5.2$ & 5.1 & 3.9 & 7.6 \\
\hline
\end{tabular}

* from the OPGC database on cloud chemical composition at the puy de Dôme station: http://wwwobs.univ-bpclermont.fr/SO/beam/data.php.

Briefly, $50 \mathrm{ml}$ of cloud water were collected and kept cold until laboratory investigations that were started within a few hours after sampling. Ten minutes before incubation, half of the volume of the cloud water sample was sterilized by filtration $(0.22 \mu \mathrm{m}$ porosity, nylon filter) to be considered as the "reference sample" free of microorganisms. The other half was kept intact with its endogenous microflora, and both subsamples were incubated under agitation $(200 \mathrm{rpm})$ during $120 \mathrm{~h}$. The incubation temperature was $12^{\circ} \mathrm{C}$ to fit the temperature of the natural cloud. Every $24 \mathrm{~h}, 1 \mathrm{ml}$ was taken out and frozen until ion chromatography analyses.

\subsection{Analyses by ion chromatography}

Artificial solutions and the natural cloud water samples were analyzed using ion chromatography Dionex DX320 for anions (column AS11, eluent $\mathrm{KOH}$ ) and Dionex ICS1500 for cations (column CS16, eluent hydroxymethanesulfonate acid) (Jaffrezo et al., 1998; Marinoni et al., 2004). Samples were thawed $15 \mathrm{~min}$ before their dilution in ultrapure water, and transferred in vials $(5 \mathrm{ml})$ previously rinsed with ultrapure water. No chemical transformations were observed in our sample after one freeze/thaw cycle. The accuracy of ion chromatographic analyses is $10 \%$ for samples 10 times the detection limit, and around $50 \%$ for samples twice the detection limit (Marinoni et al., 2004).

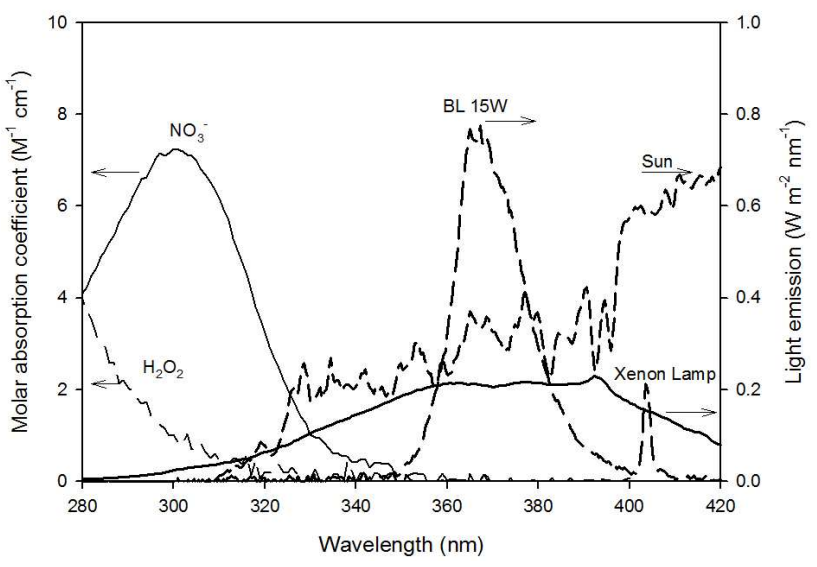

Fig. 1. Emission spectra of the $1000 \mathrm{~W}$ xenon lamp (P1), of the Philips Actinic BL $15 \mathrm{~W}$ lamps (P2), of the Sun at the Earth's surface and molar absorption coefficients of nitrate and $\mathrm{H}_{2} \mathrm{O}_{2}$ aqueous solutions.

\subsection{Calculations of bio- and photo-degradation rates}

To calculate the initial bio- and photo-degradation rates, time evolution of each carboxylic acid concentration was plotted (Fig. S1 for illustration). Then the pseudo-first order decay " $k$ " $\left(\mathrm{s}^{-1}\right)$ is determined by the linear regression of:

$\ln \left([C] /[C]_{0}\right)=f(t)=-k \times t$ (see Fig. S2). 
With $[C]_{0}\left(\mathrm{moll}^{-1}\right)$ the initial concentrations of selected carboxylic acid $C$.

In biodegradation experiments, the pseudo-first order decays was determined over the 6 and the 8 first hours of incubation at $17^{\circ} \mathrm{C}$ and $5^{\circ} \mathrm{C}$, respectively. For all strains tested in these experiments, no cellular growth was observed in the 24 first hours of incubation at 5 and $17^{\circ} \mathrm{C}$. After the 48 first hours of incubation, the cell growth factor was between 1 and 1.8 .

In photo-degradation experiments, the pseudo-first order decays were determined over the 4 and the 8 first hours of irradiation in the photochemical setups $\mathrm{P} 1$ and $\mathrm{P} 2$, respectively; at this incubation time, $\mathrm{H}_{2} \mathrm{O}_{2}$ was available since it was totally consumed after $6 \mathrm{~h}$ in $\mathrm{P} 1$ and $48 \mathrm{~h}$ in $\mathrm{P} 2$.

The measured degradation rates of the compound $C\left(v_{\mathrm{c}}\right)$ have been determined as follows:

- for biodegradation rates per cell:

$$
v_{\mathrm{c}}=\left(k \times[C]_{0}\right) / N_{\text {cells }}\left[\mathrm{mol} \mathrm{cell}{ }^{-1} \mathrm{~s}^{-1}\right]
$$

- for photodegradation rates:

$$
v_{\mathrm{c}}=k \times[C]_{0}\left[\mathrm{Ms}^{-1}\right]
$$

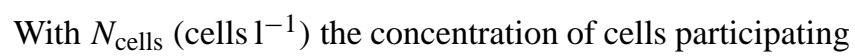
to the biodegradation.

The estimated photodegradation rates resulting from the reactivity with free radicals from data of the literature:

$v_{\mathrm{c}}=K \times\left[{ }^{\bullet} \mathrm{OH}\right] \times[C]_{0}\left[\mathrm{Ms}^{-1}\right]$

with $[C]_{0}$ the initial concentrations of selected carboxylic acid $C\left(\mathrm{moll}^{-1}\right),[\mathrm{OH}]$ is the concentration of free radical $\mathrm{OH}$ from literature and $\mathrm{K}\left(\mathrm{M}^{-1} \mathrm{~s}^{-1}\right)$ is the degradation rate constant of the carboxylic acid $\mathrm{C}$ by $\mathrm{OH}$.

\section{Results}

\subsection{Biodegradation}

\subsubsection{Artificial cloud media}

The artificial cloud water media used in these experiments contained the 4 major carboxylic compounds dominating the soluble organic composition of clouds (acetate, formate, succinate, and oxalate) and 8 major inorganic ions (see composition in Table 1). The inorganic composition differed by higher sodium and chloride concentrations in "marine" than in "continental" medium and inversely for nitrate, ammonium, and sulfate. The continental medium was more acidic $(\mathrm{pH} \sim 5)$ than the marine one $(\mathrm{pH} \sim 6.3)$. The organic compositions in "marine" and in "continental" media were similar to allow comparisons of the measured biotransformation rates and to detect possible effects of the concentration of inorganic ions and of the $\mathrm{pH}$ on the metabolic activity of microorganisms.

These media were incubated with a pure microbial culture at $5^{\circ} \mathrm{C}$ and $17^{\circ} \mathrm{C}$. The colder temperature $\left(5^{\circ} \mathrm{C}\right)$ corresponds to the mean annual value measured at the puy de Dôme summit, while $17^{\circ} \mathrm{C}$ is approximately the maximal temperature observed there when a cloud forms (see http://wwwobs.univ-bpclermont.fr/SO/mesures/pdd.php).

During the incubation period, only the degradation of organic species was observed and no extracellular accumulation of intermediary carboxylic acids was detected. The measured rates of biotransformation per cell of each compound by each microbial strain are reported in Table 2 . The value "zero" was considered when no degradation was detected and was taken into account in the calculation of the average biodegradation rate presented further. Nine and eight strains out of seventeen were able to degrade carboxylic acids at $17^{\circ} \mathrm{C}$ and $5{ }^{\circ} \mathrm{C}$, respectively. Although some of the microorganisms used could have the enzymatic material necessary for transforming oxalate (Sahin, 2003), none was degrading it under our incubation conditions. Biodegradation rates per cell of acetate ranged from 0 to $7 \times 10^{-18} \mathrm{~mol} \mathrm{cell}^{-1} \mathrm{~s}^{-1}$ (strain $14 \mathrm{~b} 10$, "continental" medium) at $17^{\circ} \mathrm{C}$, and from 0 to $2 \times 10^{-18} \mathrm{~mol} \mathrm{cell}^{-1} \mathrm{~s}^{-1}$ (strains $14 \mathrm{~b} 10$ and $23 \mathrm{~b} 5$, continental) at $5^{\circ} \mathrm{C}$. For formate, they reached $1 \times 10^{-17} \mathrm{~mol} \mathrm{cell}^{-1} \mathrm{~s}^{-1}$ (strain $6 \mathrm{~b} 4$, continental) at $17^{\circ} \mathrm{C}$, and $5 \times 10^{-18} \mathrm{~mol} \mathrm{cell}^{-1} \mathrm{~s}^{-1}$ (strain $12 \mathrm{~b} 8$, marine) at $5{ }^{\circ} \mathrm{C}$. For succinate, biodegradation rates per cell ranged 0 to $1 \times 10^{-18} \mathrm{molcell}^{-1} \mathrm{~s}^{-1}$ (strains $3 \mathrm{~b} 1$ and $13 \mathrm{~b} 2$, marine) at $17^{\circ} \mathrm{C}$, and from 0 to $3 \times 10^{-19} \mathrm{molcell}^{-1} \mathrm{~s}^{-1}$ (strain $13 \mathrm{~b} 2$, marine) at $5{ }^{\circ} \mathrm{C}$.

Except in a few cases (Pseudomonas toward acetate at $5^{\circ} \mathrm{C}$ ), Pseudomonas strains and Rhodococcus were active towards all the tested compounds. On the contrary, Bacillus, Arthrobacter, Clavibacter, and Frigoribacterium strains were not able to degrade any of those under any of our experimental conditions. One of the three Sphingomonas strains tested was able to degrade formate and succinate at $17^{\circ} \mathrm{C}$, but none at $5{ }^{\circ} \mathrm{C}$.

Regarding the influence of the chemical composition on the degradation rates, $55 \%$ of the measured biodegradation rates per cell were higher in marine medium than in continental cloud water solution. However, no significant difference of the average biodegradation rate per cell of a given compound between these two artificial media was observed. Some strains degraded carboxylic acids more efficiently in the marine than in the continental medium, and vice versa.

As expected, when detected, activities of biodegradation at $5^{\circ} \mathrm{C}$ were lower than at $17^{\circ} \mathrm{C}$ by factors ranging from 2.1 to 5.5 (considering the average biodegradation rates). No relationship between the chemical composition of the incubation medium and the temperature dependence of biodegradation activities was detected. 
Table 2. Measured rates of biodegradation of carboxylic acids by pure strains at 5 and $17^{\circ} \mathrm{C}$ in the "marine" and "continental" artificial cloud water media.

\begin{tabular}{|c|c|c|c|c|c|c|c|}
\hline & & \multicolumn{3}{|c|}{ Marine } & \multicolumn{3}{|c|}{ Continental } \\
\hline & \multirow[t]{2}{*}{$17^{\circ} \mathrm{C}$} & \multicolumn{6}{|c|}{ Rates of biodegradation per cell $\left(\mathrm{mol} \mathrm{cell}{ }^{-1} \mathrm{~s}^{-1}\right)^{*}$} \\
\hline & & Acetate & Formate & Succinate & Acetate & Formate & Succinate \\
\hline $3 b-10$ & Sphingomonas sp. & 0 & 0 & 0 & 0 & 0 & 0 \\
\hline $14 b-5$ & Sphingomonas sp. & 0 & $2 \times 10^{-19}$ & $2 \times 10^{-19}$ & 0 & $2 \times 10^{-19}$ & $3 \times 10^{-19}$ \\
\hline $14 b-6$ & Sphingomonas sp. & 0 & 0 & 0 & 0 & 0 & 0 \\
\hline $6 b-4$ & Pseudomonas sp. & $7 \times 10^{-19}$ & $1 \times 10^{-18}$ & $1 \times 10^{-19}$ & $5 \times 10^{-19}$ & $1 \times 10^{-17}$ & $6 \times 10^{-19}$ \\
\hline $14 b-10$ & Pseudomonas sp. & $2 \times 10^{-18}$ & $2 \times 10^{-18}$ & $2 \times 10^{-19}$ & $7 \times 10^{-18}$ & $7 \times 10^{-18}$ & $3 \times 10^{-19}$ \\
\hline $3 b-1$ & Pseudomonas syringae & $1 \times 10^{-18}$ & $2 \times 10^{-18}$ & $1 \times 10^{-18}$ & $5 \times 10^{-19}$ & $1 \times 10^{-18}$ & $4 \times 10^{-19}$ \\
\hline $12 b-8$ & Pseudomonas syringae & $6 \times 10^{-19}$ & $8 \times 10^{-18}$ & $4 \times 10^{-20}$ & $2 \times 10^{-18}$ & $2 \times 10^{-18}$ & $5 \times 10^{-19}$ \\
\hline $13 b-2$ & Pseudomonas syringae & $1 \times 10^{-18}$ & $3 \times 10^{-18}$ & $1 \times 10^{-18}$ & $4 \times 10^{-19}$ & $2 \times 10^{-18}$ & $6 \times 10^{-19}$ \\
\hline $13 b-3$ & Pseudomonas graminis & $4 \times 10^{-19}$ & $5 \times 10^{-18}$ & $5 \times 10^{-19}$ & $5 \times 10^{-19}$ & $4 \times 10^{-18}$ & $4 \times 10^{-19}$ \\
\hline $14 b-14$ & Pseudomonas viridiflava & $9 \times 10^{-19}$ & $2 \times 10^{-18}$ & $6 \times 10^{-19}$ & $9 \times 10^{-20}$ & $7 \times 10^{-19}$ & $1 \times 10^{-19}$ \\
\hline 16b-1 & Bacillus sp. & 0 & 0 & 0 & 0 & 0 & 0 \\
\hline $5 b-1$ & Bacillus pumilus & 0 & 0 & 0 & 0 & 0 & 0 \\
\hline $3 b-7$ & Arthrobacter rhombi & 0 & 0 & 0 & 0 & 0 & 0 \\
\hline $14 b-13$ & Clavibacter michiganensis & 0 & 0 & 0 & 0 & 0 & 0 \\
\hline 30b-1 & Frigoribacterium sp. & 0 & 0 & 0 & 0 & 0 & 0 \\
\hline $14 b-13$ & Frigoribacterium sp. & 0 & 0 & 0 & 0 & 0 & 0 \\
\hline $23 b-5$ & Rhodococcus sp. & $5 \times 10^{-18}$ & $8 \times 10^{-19}$ & $5 \times 10^{-20}$ & $4 \times 10^{-18}$ & $1 \times 10^{-18}$ & $7 \times 10^{-20}$ \\
\hline \multicolumn{2}{|c|}{ Microbial average rate } & $7 \times 10^{-19}$ & $1 \times 10^{-18}$ & $2 \times 10^{-19}$ & $8 \times 10^{-19}$ & $2 \times 10^{-18}$ & $2 \times 10^{-19}$ \\
\hline & $5^{\circ} \mathrm{C}$ & & & & & & \\
\hline $3 b-10$ & Sphingomonas sp. & 0 & 0 & 0 & 0 & 0 & 0 \\
\hline $14 b-5$ & Sphingomonas sp. & 0 & 0 & 0 & 0 & 0 & 0 \\
\hline $14 b-6$ & Sphingomonas sp. & 0 & 0 & 0 & 0 & 0 & 0 \\
\hline $6 b-4$ & Pseudomonas sp. & $5 \times 10^{-19}$ & $6 \times 10^{-19}$ & $3 \times 10^{-20}$ & $2 \times 10^{-19}$ & $2 \times 10^{-18}$ & $1 \times 10^{-19}$ \\
\hline $14 b-10$ & Pseudomonas sp. & $7 \times 10^{-19}$ & $1 \times 10^{-18}$ & $9 \times 10^{-21}$ & $2 \times 10^{-18}$ & $3 \times 10^{-18}$ & $8 \times 10^{-21}$ \\
\hline $3 b-1$ & Pseudomonas syringae & 0 & $4 \times 10^{-19}$ & $2 \times 10^{-19}$ & 0 & $2 \times 10^{-19}$ & $4 \times 10^{-20}$ \\
\hline $12 b-8$ & Pseudomonas syringae & $2 \times 10^{-19}$ & $5 \times 10^{-18}$ & $3 \times 10^{-20}$ & $2 \times 10^{-19}$ & $9 \times 10^{-19}$ & $1 \times 10^{-19}$ \\
\hline $13 b-2$ & Pseudomonas syringae & 0 & $1 \times 10^{-18}$ & $3 \times 10^{-19}$ & 0 & $6 \times 10^{-19}$ & $2 \times 10^{-19}$ \\
\hline $13 b-3$ & Pseudomonas graminis & $1 \times 10^{-19}$ & $1 \times 10^{-18}$ & $1 \times 10^{-19}$ & $5 \times 10^{-20}$ & $7 \times 10^{-19}$ & $7 \times 10^{-20}$ \\
\hline $14 b-14$ & Pseudomonas viridiflava & 0 & $6 \times 10^{-19}$ & $7 \times 10^{-20}$ & 0 & $9 \times 10^{-20}$ & $1 \times 10^{-20}$ \\
\hline 16b-1 & Bacillus sp. & 0 & 0 & 0 & 0 & 0 & 0 \\
\hline $5 b-1$ & Bacillus pumilus & 0 & 0 & 0 & 0 & 0 & 0 \\
\hline $3 b-7$ & Arthrobacter rhombi & 0 & 0 & 0 & 0 & 0 & 0 \\
\hline $25 b-3$ & Clavibacter michiganensis & 0 & 0 & 0 & 0 & 0 & 0 \\
\hline $14 b-13$ & Frigoribacterium sp. & 0 & 0 & 0 & 0 & 0 & 0 \\
\hline 30b-1 & Frigoribacterium sp. & 0 & 0 & 0 & 0 & 0 & 0 \\
\hline $23 b-5$ & Rhodococcus sp. & $1 \times 10^{-18}$ & $4 \times 10^{-19}$ & $4 \times 10^{-20}$ & $2 \times 10^{-18}$ & $8 \times 10^{-19}$ & $4 \times 10^{-20}$ \\
\hline \multicolumn{2}{|c|}{ Microbial average rate } & $2 \times 10^{-19}$ & $6 \times 10^{-19}$ & $5 \times 10^{-20}$ & $2 \times 10^{-19}$ & $4 \times 10^{-19}$ & $4 \times 10^{-20}$ \\
\hline
\end{tabular}

* Global experimental uncertainties result from two additive errors: (1) the one from the analysis with the ionic chromatography (less than $10 \%$ ); (2) the one from the biological variability that was calculated from five replicates on 2 strains (between 20 and $25 \%$ ).

\subsubsection{Natural cloud}

Natural cloud water was used without any chemical modification and in the presence of its own microflora. The chemical composition of this cloud water sample is given in Table 1 and present concentrations typical from continental influence and similar to the composition from the artificial continental cloud medium.

The cloud water was incubated at $12{ }^{\circ} \mathrm{C}$ and the biodegradation of organic acids was monitored. Under this condition, 
Table 3. Estimated rates of photo- and bio-degradation in artificial cloud water at $17^{\circ} \mathrm{C}$.

\begin{tabular}{|c|c|c|c|c|c|c|c|c|}
\hline \multirow{3}{*}{$17^{\circ} \mathrm{C}$} & \multicolumn{4}{|c|}{ Marine } & \multicolumn{4}{|c|}{ Continental } \\
\hline & \multicolumn{8}{|c|}{ Rate of degradation $\left(\mathrm{M} \mathrm{s}^{-1}\right)$} \\
\hline & Acetate & Formate & Succinate & Oxalate & Acetate & Formate & Succinate & Oxalate \\
\hline $\mathrm{P} 1^{*}$ & 0 & $7.1( \pm 2.2) \times 10^{-10}$ & 0 & $2.7( \pm 1.2) \times 10^{-10}$ & 0 & $7.4( \pm 2.1) \times 10^{-10}$ & 0 & $3.4( \pm 0.9) \times 10^{-10}$ \\
\hline $\mathrm{P} 2^{*}$ & 0 & $0.2( \pm 0.1) \times 10^{-10}$ & 0 & $0.2( \pm 0.1) \times 10^{-10}$ & 0 & $1.5( \pm 0.4) \times 10^{-10}$ & 0 & $1.9( \pm 0.7) \times 10^{-10}$ \\
\hline Microbial** & $6.6( \pm 9.1) \times 10^{-11}$ & $1.2( \pm 1.8) \times 10^{-10}$ & $2.4( \pm 3.2) \times 10^{-11}$ & 0 & $8.3( \pm 1.4) \times 10^{-11}$ & $1.7( \pm 2.3) \times 10^{-10}$ & $1.9( \pm 1.8) \times 10^{-11}$ & 0 \\
\hline
\end{tabular}

* Photodegradation rates ( \pm absolute uncertainties for 3 replicates) determined experimentally in $\mathrm{M} \mathrm{s}^{-1}$. ** Biodegradation rates expressed in $\mathrm{M} \mathrm{s}{ }^{-1}$ is calculated by considering the average biodegradation rates per cell (in mol cell ${ }^{-1} \mathrm{~s}^{-1}$ ) (see Table 2) and the cellular concentration equal to $8 \times 10^{7}$ cells $1^{-1}$ (mean value observed in natural cloud water sampled at the puy de Dôme station, Amato et al., 2007c).

acetate, formate and succinate were degraded while oxalate was not. The measured biodegradation rates were $1.2 \times 10^{-10}, 0.9 \times 10^{-10}$ and $3.3 \times 10^{-11} \mathrm{M} \mathrm{s}^{-1}$, for acetate, formate and succinate, respectively. In the reference sample free of microbes, carboxylic acids were not transformed during the incubation period.

To compare these rates with the one measured in artificial microcosms, we converted the average biodegradation rates per cell (molcell ${ }^{-1} \mathrm{~s}^{-1}$ ) obtained for the 17 bacterial strains at $17^{\circ} \mathrm{C}$ into biodegradation rates expressed in $\mathrm{Ms}^{-1}$. For that, we have considered the mean bacterial concentration in cloud water sampled at the puy de Dôme station to $8 \times 10^{7}$ cells $1^{-1}$. We obtained the following rates: $0.7 \times 10^{-10}, 1.4 \times 10^{-10}, 1.5 \times 10^{-11} \mathrm{M} \mathrm{s}^{-1}$, for acetate, formate and succinate, respectively (see Table 3 ).

These values are on the same order of magnitude than values obtained at $12{ }^{\circ} \mathrm{C}$ in the natural cloud. This shows that our artificial microcosms are a rather good experimental model to mimic real cloud water. To constitute our microcosms of cloud water, a panel of strains representative of the bacteria usually encountered in cloud water was chosen along with typical chemical compositions and cell numbers in natural clouds. Using this very simplified setup, we were able to reproduce the results obtained with a natural cloud sample whose composition is usually much more complex (more diverse organic and inorganic compounds, presence of HUmic Like Substances (HULIS), wider biodiversity, etc.).

\subsection{Photodegradation in artificial cloud water media}

To compare microbial and photochemical activities on carboxylic acid transformations, irradiation experiments were conducted in the artificial cloud solutions. Preliminary irradiation tests with no supplementation of $\mathrm{H}_{2} \mathrm{O}_{2}$ showed, as expected, that no direct photochemical degradation of carboxylic acids happened in both photochemical setups.

In the presence of $\mathrm{H}_{2} \mathrm{O}_{2}$, no organic oxidation products were detected by ion chromatography analyses. The photodegradation rates of carboxylic acids in "marine" and "continental" media measured at $17^{\circ} \mathrm{C}$ in experimental setups P1 and $\mathrm{P} 2$ are given in Table 3.
Acetate and succinate were not degraded by photolysis in all experiments. In the experimental setup P1, there was no influence of the incubation medium ("marine" or "continental") on the photodegradation rates of formate and oxalate $\left(\sim 7 \times 10^{-10} \mathrm{M} \mathrm{s}^{-1}\right.$ and $\sim 3 \times 10^{-10} \mathrm{M} \mathrm{s}^{-1}$ for formate and oxalate, respectively). In P2, the degradation rates of formate and oxalate were higher in continental than in marine medium by about one order of magnitude $\left(\sim 2 \times 10^{-10} \mathrm{M} \mathrm{s}^{-1}\right.$ and $\sim 2 \times 10^{-11} \mathrm{M} \mathrm{s}^{-1}$ in continental and in marine medium, respectively, for both species). The difference of $\mathrm{pH}$ is thought not to influence the production of hydroxyl radical from photolysis of $\mathrm{H}_{2} \mathrm{O}_{2}$ and nitrates (Mack and Bolton, 1999). We can expect the difference of behaviour observed between continental and marine solutions to be due the relative contribution of nitrate and $\mathrm{H}_{2} \mathrm{O}_{2}$ to the total concentration of free radicals in $\mathrm{P} 1$ and $\mathrm{P} 2$ which is directly related to the respective light emission spectra. Nitrate concentration in continental medium was about 3 times higher than in marine medium $(70$ and $200 \mu \mathrm{M}$ in marine and in continental medium, respectively). In the setup $\mathrm{P} 1$, the smallest emission wavelength was $\sim 290 \mathrm{~nm}$ (Fig. 1) and the formation of hydroxyl radicals was mainly attributed to the photolysis of $\mathrm{H}_{2} \mathrm{O}_{2}$. Hence, there was no or very little influence of the concentration of nitrates on the concentration of total free radicals. In the setup P2, the smallest emission wavelength was $\sim 340 \mathrm{~nm}$ (Fig. 1) and the photolysis rate of $\mathrm{H}_{2} \mathrm{O}_{2}$ was lower than in $\mathrm{P} 1$. Consequently, the relative contribution of nitrates to the concentration of total free radicals was higher in P2 than in P1 and could explain the differences observed between irradiations of "marine" and "continental" cloud solutions.

\subsection{Comparison of microbial and photochemical experiments}

Biodegradation rates measured in artificial cloud media were compared with the photodegradation rates resulting from irradiation in $\mathrm{P} 1$ and $\mathrm{P} 2$. The aim was to evaluate the relative contribution of microbial activity and of photochemistry on the fate of carboxylic acids. The estimated degradation rates of carboxylic compounds in artificial cloud water by microorganisms and photochemical processes at $17^{\circ} \mathrm{C}$ are 

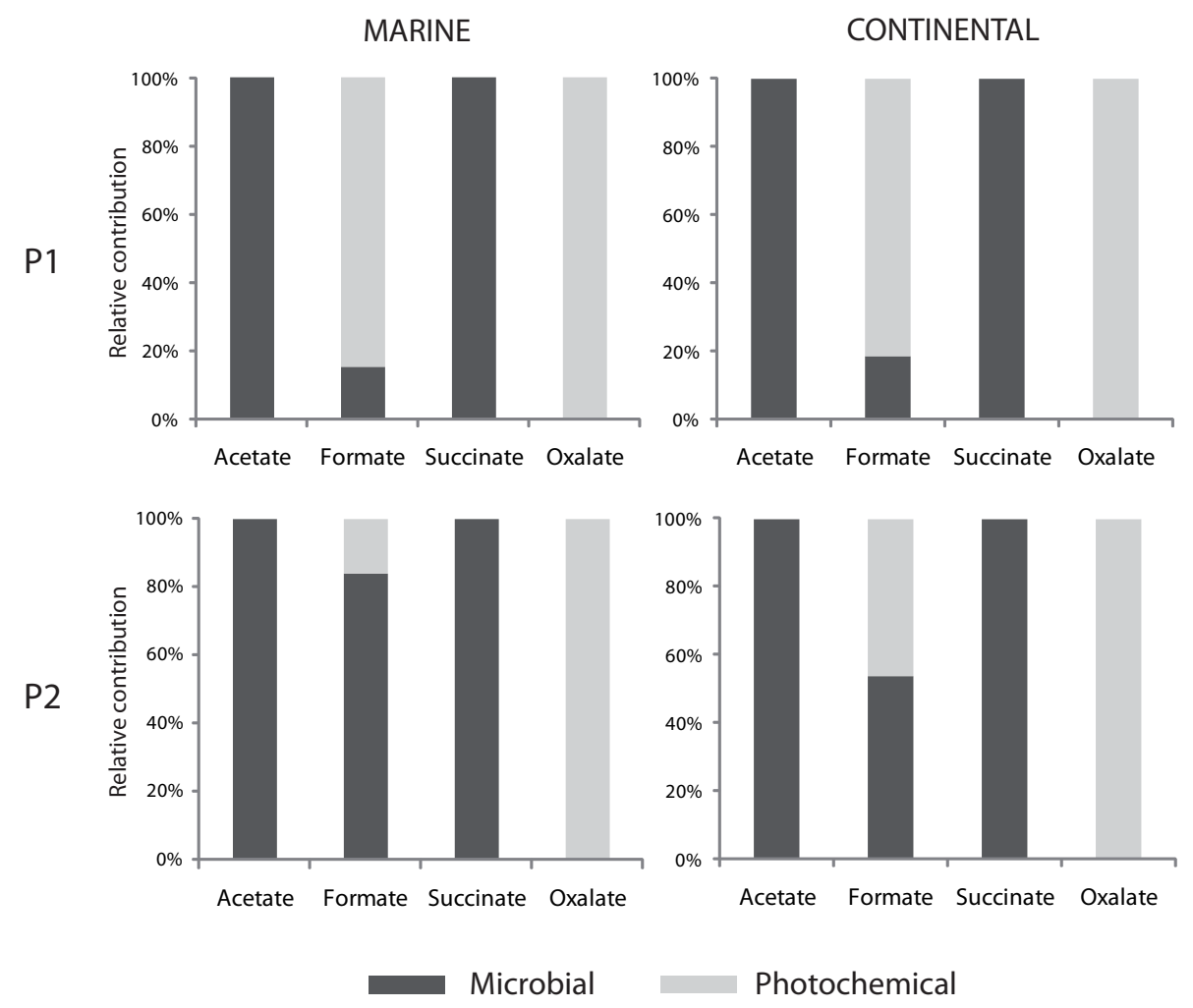

Fig. 2. Microbial and photochemical relative contributions to the degradation of carboxylic compounds in "marine" (left side) and "continental" (right side) artificial cloud media at $17^{\circ} \mathrm{C}$ and $5^{\circ} \mathrm{C}$. P1 and $\mathrm{P} 2$ correspond to the 2 irradiation setups. This figure is based on the experimental photodegradation and biodegradation rates shown in Table 3.

given in Table 3. The values provided for microbial degradation correspond to the average of the biodegradation rates given in Table 2. Figure 2 shows, for marine and continental cloud media, the relative contribution of biodegradation and of photochemistry to the degradation of acetate, formate, succinate and oxalate.

Considering the values of photodegradation rates obtained in P1 and P2, only microbial activity participated to the degradation of acetate and succinate, while oxalate was exclusively degraded by photochemical processes. For formate, microbial activity in the marine and continental medium contributes to $14 \%$ and $83 \%$ of its degradation in $\mathrm{P} 1$ and $\mathrm{P} 2$, respectively; in the continental medium, microbial contribution to the degradation of formate are equal to $16 \%$ and $48 \%$ respectively.

\section{Atmospheric implications}

The aim of this laboratory study was to measure biodegradation and photodegradation rates of organic acids under the same experimental conditions to quantify the relative contribution of microorganisms in cloud chemistry vs. photochemistry. Our results have shown that these degradation rates were on the same range of order, and suggested thus that microbes could be competitive with solar light.

However, we unexpectedly found the photodegradation rates of acetate and succinate to be undetectable in the two photo-reactors used for these experiments. In order to test other photochemical scenarios, we made a theoretical study taking into account hydroxyl radical concentrations in cloud water simulated by cloud chemistry models and the available reaction rate constants of the studied carboxylic compounds with this radical (Chin and Wine, 1994; Ervens et al., 2003b). The simulated aqueous $\mathrm{OH}$ concentrations from several models are displayed in Table 4. Since the 80's, these numerical tools were developed (Graedel et al., 1986; Jacob et al., 1989) and were based on up-to-date chemical mechanisms that contained explicit chemical processes in the aqueous phase (Herrmann et al., 2005; Tilgner and Herrmann, 2010). They also considered complex microphysical processes that redistribute chemical species among the various phases of the cloud (Leriche et al., 2001; Wolke et al., 2005). Simulated $\mathrm{OH}$ concentrations are dependent on the chemical scheme that is considered in the model and also on the cloud microphysical properties that control the mass transfer between the liquid and gas phases. As shown in Table 4, the concentrations reported in the literature can differ by two orders of magnitude depending mainly on the chemical 
Table 4. Maximum aqueous $\mathrm{OH}$ concentrations simulated by various multiphase cloud chemistry models. These models consider different explicit chemical mechanisms and simulate clouds with different microphysical properties (monodisperse to polydisperse).

\begin{tabular}{|c|c|c|c|c|}
\hline $\begin{array}{l}\text { Chemical } \\
\text { mechanisms }\end{array}$ & Cloud simulation & Chemical scenario & $\begin{array}{l}\text { Simulated } \mathrm{OH} \\
\text { concentration } \\
(\max )(\mathrm{M})\end{array}$ & References \\
\hline $\begin{array}{l}\text { Aqueous: } \\
\text { Chemistry of some } \\
\text { inorganic and organic } \\
\text { compounds }\end{array}$ & $\begin{array}{l}\text { - Permanent } \\
\text { - Monodisperse }\end{array}$ & - Polluted cloud & $2 \times 10^{-13}$ & Graedel et al. (1986) \\
\hline $\begin{array}{l}\text { Gas phase: Lurmann } \\
\text { et al. (1986) Aqueous } \\
\text { phase: } \\
\text { Chemistry of some } \\
\text { inorganic and organic } \\
\text { compounds }\end{array}$ & $\begin{array}{l}\text { - Permanent } \\
\text { - Polydisperse }\end{array}$ & - Polluted cloud & $1.6 \times 10^{-14}$ & Jacob et al. (1989) \\
\hline $\begin{array}{l}\text { Gas phase: } \\
\text { RACM } \\
\text { Aqueous phase: }\end{array}$ & $\begin{array}{l}\text { - Permanent } \\
\text { - Monodisperse }\end{array}$ & $\begin{array}{l}\text { - Remote } \\
\text { - Urban } \\
\text { - Marine }\end{array}$ & $\begin{array}{l}2 \times 10^{-13} \\
1 \times 10^{-13} \\
4.5 \times 10^{-13}\end{array}$ & Ervens et al. (2003a) \\
\hline $\begin{array}{l}\text { CAPRAM } 3.0 \\
\text { Chemistry of inorganic }\end{array}$ & $\begin{array}{l}\text { - Permanent } \\
\text { - Polydisperse }\end{array}$ & - Remote & $1.4 \times 10^{-13}$ & Herrmann et al. (2005) \\
\hline \multirow[t]{2}{*}{$\begin{array}{l}\text { and organic compounds } \\
\text { (up to } 5 \text { carbon atoms) }\end{array}$} & $\begin{array}{l}\text { - Non-permanent } \\
\text { - Polydisperse }\end{array}$ & $\begin{array}{l}\text { - Remote } \\
\text { - Urban }\end{array}$ & $\begin{array}{l}5 \times 10^{-14} \\
1 \times 10^{-14}\end{array}$ & $\begin{array}{l}\text { Tilgner and Herrmann } \\
\text { (2010) }\end{array}$ \\
\hline & $\begin{array}{l}\text { - Non-permanent } \\
\text { - Polydisperse }\end{array}$ & $\begin{array}{l}\text { - Remote } \\
\text { - Urban } \\
\text { - Marine }\end{array}$ & $\begin{array}{l}1.6 \times 10^{-14} \\
6.9 \times 10^{-14} \\
5.3 \times 10^{-12}\end{array}$ & Herrmann et al. (2010) \\
\hline $\begin{array}{l}\text { Gas: Madronich and } \\
\text { Calvert (1990) }\end{array}$ & $\begin{array}{l}\text { - Monodisperse } \\
\text { - Permanent }\end{array}$ & - Polluted cloud & $2 \times 10^{-14}$ & Leriche et al. (2001) \\
\hline \multirow{3}{*}{$\begin{array}{l}\text { Aqueous: chemistry of } \\
\text { inorganic and organic } \\
\text { compounds (up to } 2 \\
\text { carbon atoms) }\end{array}$} & $\begin{array}{l}\text { - Permanent } \\
\text { - Monodisperse }\end{array}$ & $\begin{array}{l}\text { - Remote } \\
\text { - Urban }\end{array}$ & $\begin{array}{l}1.7 \times 10^{-12} \\
1 \times 10^{-12}\end{array}$ & Deguillaume et al. (2004) \\
\hline & $\begin{array}{l}\text { - Polydisperse } \\
\text { - Non-permanent }\end{array}$ & - Polluted cloud & $7 \times 10^{-14}$ & Leriche et al. (2007) \\
\hline & $\begin{array}{l}\text { - Monodisperse } \\
\text { - Permanent }\end{array}$ & - Remote & $3.5 \times 10^{-13}$ & Deguillaume et al. (2010) \\
\hline
\end{tabular}

scenario (marine, remote, or urban) and on the microphysical scheme. For our calculation, we decided to consider maximum $\mathrm{OH}$ concentrations (simulated at noon and during summertime) that range from $1 \times 10^{-12}$ to $1 \times 10^{-14} \mathrm{M}$. We selected the most extreme $\mathrm{OH}$ concentrations to evaluate the role of biodegradation in the most "unfavourable" conditions.

To compare these theoretical photodegradation rates to microbial activity, we used the average of biodegradation rates measured in our "continental" and "marine" artificial media (Table 5). The activity of microorganisms is clearly temperature dependant; however the activity of microbes only decreased by a factor 2 to 5 when the temperature shifted from $17^{\circ} \mathrm{C}$ to $5^{\circ} \mathrm{C}$. The relative contributions of microbial activity vs. radical chemistry for the various scenarios and the two temperatures are shown in Fig. 3.
During the day and for the highest $\mathrm{OH}$ concentrations (i.e. $\left.1 \times 10^{-12} \mathrm{M}\right)$, microbial activity has clearly a minor contribution both at $17^{\circ} \mathrm{C}$ and $5^{\circ} \mathrm{C}$. It would contribute to $4.8 \%$ $\left(17^{\circ} \mathrm{C}\right)$ or $2.0 \%\left(5^{\circ} \mathrm{C}\right)$ of the degradation of acetate, $2.6 \%$ $\left(17^{\circ} \mathrm{C}\right)$ or $0.6 \%\left(5^{\circ} \mathrm{C}\right)$ for succinate, and would be negligible for formate $\left(0.4 \%\right.$ at $17^{\circ} \mathrm{C}$ and $0.2 \%$ at $\left.5^{\circ} \mathrm{C}\right)$. However, at lower $\mathrm{OH}$ concentrations (i.e. $1 \times 10^{-14} \mathrm{M}$ ), microbial contribution could become very important compared to radical chemistry: $27.3 \%\left(17^{\circ} \mathrm{C}\right)$ and $13.6 \%\left(5^{\circ} \mathrm{C}\right)$ for formate, $83.5 \%\left(17^{\circ} \mathrm{C}\right)$ and $67.6 \%\left(5^{\circ} \mathrm{C}\right)$ for acetate, $72.5 \%$ $\left(17^{\circ} \mathrm{C}\right)$ and $37.5 \%\left(5^{\circ} \mathrm{C}\right)$ for succinate.

The contribution of microbes on the degradation of carboxylic acids does not change dramatically when decreasing the temperature from 17 to $5^{\circ} \mathrm{C}$. The main sensitive factor is clearly the concentrations of $\mathrm{OH}$ radicals that are generated 
Table 5. Experimental biodegradation rates in artificial cloud water at $17^{\circ} \mathrm{C}$ and $5{ }^{\circ} \mathrm{C}$ and calculated photodegradation rates by $\mathrm{OH}$ of acetate, formate and succinate.

\begin{tabular}{llrrr}
\hline & & Acetate & Formate & Succinate \\
\hline $17^{\circ} \mathrm{C}$ & & \multicolumn{2}{c}{ Estimated degradation rate $\left(\mathrm{M} \mathrm{s}^{-1}\right)$} \\
\hline $\mathrm{OH}^{*}$ & $10^{-12} \mathrm{M}$ & $1.2 \times 10^{-9}$ & $3.2 \times 10^{-8}$ & $6.6 \times 10^{-10}$ \\
& $10^{-14} \mathrm{M}$ & $1.2 \times 10^{-11}$ & $3.2 \times 10^{-10}$ & $6.6 \times 10^{-12}$ \\
\hline Microbial $^{* *}$ & $8 \times 10^{7}$ cells $^{-1}$ & $6.0 \times 10^{-11}$ & $1.2 \times 10^{-10}$ & $1.7 \times 10^{-11}$ \\
\hline $5^{\circ} \mathrm{C}$ & & & & \\
\hline $\mathrm{OH}^{*}$ & $10^{-12} \mathrm{M}$ & $9.1 \times 10^{-10}$ & $2.7 \times 10^{-8}$ & $5.4 \times 10^{-10}$ \\
& $10^{-14} \mathrm{M}$ & $9.1 \times 10^{-12}$ & $2.7 \times 10^{-10}$ & $5.4 \times 10^{-12}$ \\
\hline Microbial $^{* *}$ & $8 \times 10^{7}$ cells $^{-1}$ & $1.9 \times 10^{-11}$ & $4.3 \times 10^{-11}$ & $3.2 \times 10^{-12}$ \\
\hline
\end{tabular}

* The kinetic data for $\mathrm{OH}$ reactions with acetate is $k_{1}\left(25^{\circ} \mathrm{C}\right)=7.0 \times 10^{7} \mathrm{M}^{-1} \mathrm{~s}^{-1} ; E_{A, 1}=15 \mathrm{~kJ} \mathrm{~mol}^{-1}$ (Chin and Wine, 1994); with formate: $k_{2}\left(25^{\circ} \mathrm{C}\right)=(2.4 \pm 0.4) \times 10^{9} \mathrm{M}^{-1}$ $\mathrm{s}^{-1} ; E_{A, 2}=(9 \pm 5) \mathrm{kJ} \mathrm{mol}^{-1}$ and with succinate (dianion): $k_{3}\left(25^{\circ} \mathrm{C}\right)=(5.0 \pm 0.5) \times 10^{8} \mathrm{M}^{-1} \mathrm{~s}^{-1} ; E_{A, 3}=(11 \pm 5) \mathrm{kJ} \mathrm{mol}^{-1}$ (Ervens et al., $2003 \mathrm{~b}$ ).

** Biodegradation rates expressed in $\mathrm{M} \mathrm{s}^{-1}$ are calculated by considering the average biodegradation rates per cell (in mol cell ${ }^{-1} \mathrm{~s}^{-1}$ ) determined in the "marine" and "continental" media (see Table 2) and the cellular concentration equal to $8 \times 10^{7}$ cells $1^{-1}$ (see Amato et al., 2007c).

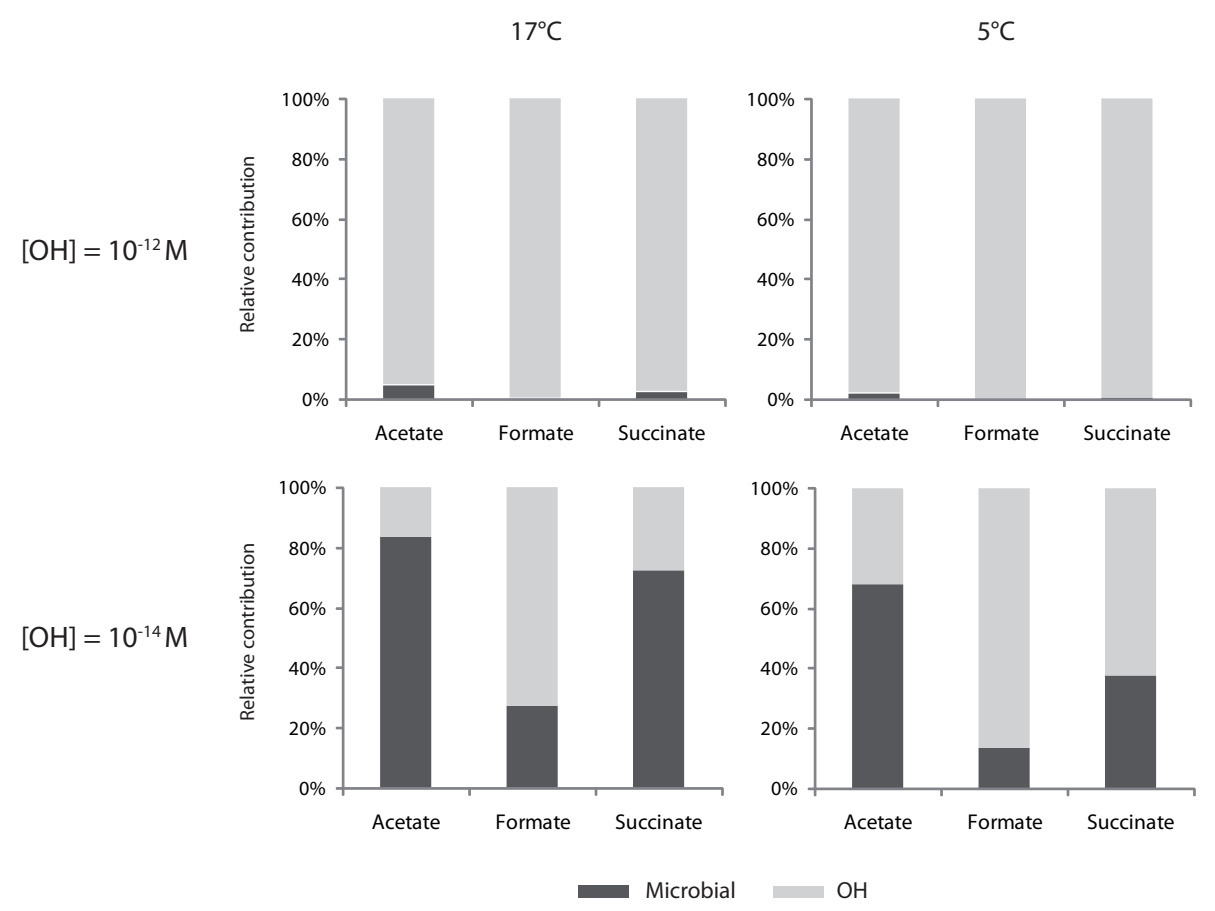

Fig. 3. Theoretical comparisons of microbial activity vs. radical chemistry to the degradation of carboxylic compounds in artificial cloud media. Relative contributions of each process were determined by comparison of biodegradation and photodegradation rates. Biodegradation rates per cell were measured experimentally (Table 2). Photodegradation rates were calculated using simulated standard $\mathrm{OH}$ concentrations in cloud water and reaction rates of $\mathrm{OH}$ towards the respective acids for two radical concentrations $\left([\mathrm{OH}]=10^{-12} \mathrm{M}\right.$ and $\left.[\mathrm{OH}]=10^{-14} \mathrm{M}\right)$ (see Table 5). 
in our photochemical setups using $\mathrm{H}_{2} \mathrm{O}_{2}$ as a precursor of $\mathrm{OH}$ or calculated from modelling studies on cloud chemistry. Our experimental results with both systems (P1 and P2) and calculations using $\mathrm{OH}$ concentration equal to $1 \times 10^{-14} \mathrm{M}$, led to similar contributions of the efficiency of microbes to degrade the studied carboxylic acids. In these conditions, microorganisms were always more efficient to degrade acetate and succinate than photodegradation; the degradation of formate was usually in favour of photodegradation vs. biodegradation; and oxalate was only photodegraded.

\section{Conclusions and perspectives}

In conclusion, this paper brings new answers to the emerging scientific question related to the relative contribution of microbial activity to atmospheric chemistry. Our results derived from laboratory experiments and theoretical calculations contribute to reinforce the validity of the hypothesis of potential microbial activity in warm clouds:

- the influence of aqueous chemical composition (continental vs. marine) does not seem to influence strongly microbial activity;

- the biodegradation rates not drastically decrease when the temperature of incubation varies from 17 to $5^{\circ} \mathrm{C}$;

- the measured biodegradation rates even at $5{ }^{\circ} \mathrm{C}$ are competitive with measured and calculated photodegradation rates especially for acetate and formate.

However more work is required to see if the conclusions obtained in this work can be applied to the more complex environments of ambient cloud droplets. Our detailed experiments have been performed in bulk media with simplified situations. These biodegradation rates might represent the upper limit of the possible biological activity taking place in real clouds where several stressful conditions for microbes can occur (evaporation/condensation cycles, strong oxidants, high UV radiation etc.). But, this first step is crucial to understand the mechanisms taking place and to highlight the potential role of microbes. Chemistry in real clouds is even more complex as it involves multiphase mechanisms and transfers. Only models will be able to reproduce these complex scenarios. In this frame, an urgent task is to experimentally measure radical concentrations in real cloud water. Future work should also combine both photo- and biodegradation experiments both in natural cloud water and in microcosms of various chemical compositions. It should include more parameters as descriptors of the processes going on in these environments. In particular the evolution of microbial population and concentrations of oxidants such as $\mathrm{H}_{2} \mathrm{O}_{2}$ during the incubation period seem to be relevant parameters to consider. To go further, in cloud processes can also contribute to the modification of pre-existing particles through new mass formation of organics and/or to new particle formation (Blando and Turpin, 2000; Lim et al., 2010). Microorganisms through the production of metabolites could potentially participate to this in-cloud process. Laboratory experiments have to be performed on individual biological processes under controlled conditions to create parameterizations that could be incorporated in cloud chemistry models. In this study, we showed that our artificial microcosms could realistically mimic real cloud water since biodegradation rates measured in these two media were in the same range. By this way, effect of biological activity on cloud chemistry could be quantified.

\section{Supplementary material related to this article is available online at: http://www.atmos-chem-phys.net/11/8721/2011/ acp-11-8721-2011-supplement.pdf.}

Acknowledgements. The research was funded by the CNRS and French Ministry of Research under LEFE-CHAT and ORE-BEAM programs. Mickael Vaïtilingom acknowledges Ph.D scholarships from the French Ministry of Research. Tiffany Charbouillot and Marius Parazols acknowledge Ph.D scholarships from the Auvergne region. Romain Maisonobe thanks the LaMP and the LPMM laboratories for their financial support. Elodie Cano, Yoann Long and Evelyn Freney are gratefully acknowledged for their technical contribution to this study. Marcello Brigante and Gilles Mailhot are gratefully acknowledged for their scientific contribution.

Edited by: B. Ervens

\section{References}

Ahern, H. E., Walsh, K. A., Hill, T. C. J., and Moffett, B. F.: Fluorescent pseudomonads isolated from Hebridean cloud and rain water produce biosurfactants but do not cause ice nucleation, Biogeosciences, 4, 115-124, doi:10.5194/bg-4-115-2007, 2007.

Amato, P., Ménager, M., Sancelme, M., Laj, P., Mailhot, G., and Delort, A.-M.: Microbial population in cloud water at the Puy de Dôme: Implications for the chemistry of clouds, Atmos. Environ., 39, 4143-4153, 2005.

Amato, P., Demeer, F., Melaouhi, A., Fontanella, S., Martin-Biesse, A.-S., Sancelme, M., Laj, P., and Delort, A.-M.: A fate for organic acids, formaldehyde and methanol in cloud water: their biotransformation by micro-organisms, Atmos. Chem. Phys., 7, 4159-4169, doi:10.5194/acp-7-4159-2007, 2007a.

Amato, P., Parazols, M., Sancelme, M., Laj, P., Mailhot, G., and Delort, A.-M.: Microorganisms isolated from the water phase of tropospheric clouds at the Puy de Dôme: major groups and growth abilities at low temperatures., FEMS Microbiol. Ecol., 59, 242-254, 2007b.

Amato, P., Parazols, M., Sancelme, M., Mailhot, G., Laj, P., and Delort, A.-M.: An important oceanic source of micro-organisms for cloud water at the Puy de Dôme (France), Atmos. Environ., $41,8253-8263,2007 \mathrm{c}$ 
Ariya, P. A., Nepotchatykh, O., Ignatova, O., and Amyot, M.: Microbiological degradation of atmospheric organic compounds, Geophys. Res. Lett., 29, 2077-2081, 2002.

Bauer, H., Kasper-Giebl, A., Löflund, M., Giebl, H., Hitzenberger, R., Zibuschka, F., and Puxbaum, H.: The contribution of bacteria and fungal spores to the organic carbon content of cloud water, precipitation and aerosols, Atmos. Res., 64, 109-119, 2002.

Blando, J. D. and Turpin, B. J.: Secondary organic aerosol formation in cloud and fog droplets: a literature evaluation of plausibility, Atmos. Environ., 34, 1623-1632, 2000.

Burrows, S. M., Elbert, W., Lawrence, M. G., and Pöschl, U.: Bacteria in the global atmosphere - Part 1: Review and synthesis of literature data for different ecosystems, Atmos. Chem. Phys., 9, 9263-9280, doi:10.5194/acp-9-9263-2009, 2009.

Carlton, A. G., Turpin, B. J., Altieri, K. E., Seitzinger, S., Reff, A., Lim, H.-J., and Ervens, B.: Atmospheric oxalic acid and SOA production from glyoxal: Results of aqueous photooxidation experiments, Atmos. Environ., 41, 7588-7602, 2007.

Casareto, B. E., Suzuki, Y., Okada, K., and Morita, M.: Biological micro-particles in rain water, Geophys. Res. Lett., 23, 173-176, 1996.

Chebbi, A. and Carlier, P.: Carboxylic acids in the troposphere, occurrence, sources, and sinks: A review, Atmos. Environ., 30, 4233-4249, 1996.

Chin, M. and Wine, P. H.: A temperature-dependent competitive kinetics study of the aqueous phase reactions of $\mathrm{OH}$ radicals with formate, formic acid, acetate, acetic acid and hydrated formaldehyde, in: Aquatic and Surface Photochemistry, edited by: Helz, G. R., Zepp, R. G., and Crosby, D. G, Lewis Publishers, Boca Raton, 85-96, 1994.

Côté, V., Kos, G., Mortazavi, R., and Ariya, P. A.: Microbial and "de novo" transformation of dicarboxylic acids by three airborne fungi, Sci. Total Environ., 390, 530-537, 2008.

Deguillaume, L., Leriche, M., Monod, A., and Chaumerliac, N.: The role of transition metal ions on $\mathrm{HO}_{\mathrm{x}}$ radicals in clouds: a numerical evaluation of its impact on multiphase chemistry, Atmos. Chem. Phys., 4, 95-110, doi:10.5194/acp-4-95-2004, 2004.

Deguillaume, L., Leriche, M., Amato, P., Ariya, P. A., Delort, A.M., Pöschl, U., Chaumerliac, N., Bauer, H., Flossmann, A. I., and Morris, C. E.: Microbiology and atmospheric processes: chemical interactions of primary biological aerosols, Biogeosciences, 5, 1073-1084, doi:10.5194/bg-5-1073-2008, 2008.

Deguillaume, L., Desboeufs, K. V., Leriche, M., Long, Y., and Chaumerliac, N.: Effect of iron dissolution on cloud chemistry: from laboratory measurements to model results, Atmos. Pol. Res., 1, 220-228, 2010.

Delort, A.-M., Vaïtilingom, M., Amato, P., Sancelme, M., Parazols, M., Mailhot, G., Laj, P., and Deguillaume, L.: A short overview of the microbial population in clouds: Potential roles in atmospheric chemistry and nucleation processes, Atmos. Res., 98, 249-260, doi:10.1016/j.physletb.2003.10.071, 2010.

Ervens, B., George, C., Williams, J. E., Buxton, G. V., Salmon, G. A., Bydder, M., Wilkinson, F., Dentener, F., Mirabel, P., Wolke, R., and Herrmann, H.: CAPRAM 2.4 (MODAC mechanism): An extended and condensed tropospheric aqueous phase mechanism and its application, J. Geophys. Res., 108, 4426, doi:10.1029/2002jd002202, 2003a.

Ervens, B., Gligorovski, S., and Herrmann, H.: Temperaturedependent rate constants for hydroxyl radical reactions with organic compounds in aqueous solutions, Phys. Chem. Chem. Phys., 5, 1811-1824, doi:10.1039/b300072a, 2003b.

Ervens, B., Feingold, G., Frost, G. J., and Kreidenweis, S. M.: A modeling study of aqueous production of dicarboxylic acids: 1 . Chemical pathways and speciated organic mass production, J. Geophys. Res., 109, D15205, doi:10.1029/2003JD004387, 2004.

Fuzzi, S., Mandrioli, P., and Perfetto, A.: Fog droplets-An atmospheric source of secondary biological aerosol particles, Atmos. Environ., 31, 287-290, 1997.

Fuzzi, S., Facchini, M. C., Decesari, S., Matta, E., and Mircea, M.: Soluble organic compounds in fog and cloud droplets: what have we learned over the past few years?, Atmos. Res., 64, 89-98, 2002.

Graedel, T. E., Mandich, M. L., and Weschler, C. J.: Kinetic model studies of Atmospheric Droplet Chemistry 2. Homogeneous Transition Metal Chemistry in Raindrops, J. Geophys. Res., 91, 5205-5221, doi:10.1029/JD091iD04p05205, 1986.

Hadi, D. A., Crossley, A., and Cape, J. N.: Particulate and dissolved organic carbon in cloud water in southern Scotland, Environ. Pollut., 88, 299-306, 1995.

Herlihy, L. J., Galloway, J. N., and Mills, A. L.: Bacterial utilization of formic and acetic acid in rainwater, Atmos. Environ., 21, 2397-2402, 1987.

Herrmann, H.: Kinetics of Aqueous Phase Reactions Relevant for Atmospheric Chemistry, Chem. Rev., 103, 4691-4716, 2003.

Herrmann, H., Tilgner, A., Barzaghi, P., Majdik, Z., Gligorovski, S., Poulain, L., and Monod, A.: Towards a more detailed description of tropospheric aqueous phase organic chemistry: CAPRAM 3.0, Atmos. Environ., 39, 4351-4363, 2005.

Herrmann, H., Hoffmann, D., Schaefer, T., Bräuer, P., and Tilgner, A.: Tropospheric Aqueous-Phase Free-Radical Chemistry: Radical Sources, Spectra, Reaction Kinetics and Prediction Tools, Chem. Phys. Chem., 11, 3796-3822, 2010.

Jacob, D. J., Munger, J. W., Waldman, J. M., and Hoffmann, M. R.: The $\mathrm{H}_{2} \mathrm{SO}_{4}, \mathrm{HNO}_{3}, \mathrm{NH}_{3}$ System at High Humidities and in Fogs 1. Spatial and Temporal Patterns in the San Joaquin Valley of California, J. Geophys. Res., 91, 1073-1088, 1986.

Jacob, D. J., Gottlieb, E. W., and Prather, M. J.: Chemistry of a Polluted Cloudy Boundary Layer, J. Geophys. Res., 94, 1297513002, doi:10.1029/JD094iD10p12975, 1989.

Jaenicke, R.: Abundance of Cellular Material and Proteins in the Atmosphere, Science, 308, p. 73, doi:10.1126/science.1106335, 2005.

Jaffrezo, J. L., Calas, N., and Bouchet, M.: Carboxylic acids measurements with ionic chromatography, Atmos. Environ., 32, 2705-2708, 1998.

Karpel Vel Leitner, N., and Doré, M.: Mechanism of the reaction between hydroxyl radicals and glycolic, glyoxylic, acetic and oxalic acids in aqueous solution: Consequence on hydrogen peroxide consumption in the $\mathrm{H}_{2} \mathrm{O}_{2} / \mathrm{UV}$ and $\mathrm{O}_{3} / \mathrm{H}_{2} \mathrm{O}_{2}$ systems, Water Res., 31, 1383-1397, 1997.

Kruisz, C., Berner, A., and Brandner, B.: A cloud water sampler for high wind speeds, Proceedings of the EUROTRAC Symposium 1992 SPB Academic Publishing bv, Den Haag, 523-525, 1993.

Laj, P., Fuzzi, S., Facchini, M. C., Lind, J. A., Orsi, G., Preiss, M., Maser, R., Jaeschke, W., Seyffer, E., Helas, G., Acker, K., Wieprecht, W., Möller, D., Arends, B. G., Mols, J. J., Colvile, R. N., Gallagher, M. W., Beswick, K. M., Hargreaves, K. J., Storeton-West, R. L., and Sutton, M. A.: Cloud processing of 
soluble gases, Atmos. Environ., 31, 2589-2598, 1997.

Lazrus, A. L., Kok, G. L., Gitlin, S. N., Lind, J. A., and McLaren, S. E.: Automated fluorimetric method for hydrogen peroxide in atmospheric precipitation, Anal. Chem., 57, 917-922, 1985.

Legrand, M., Preunkert, S., Galy-Lacaux, C., Liousse, C., and Wagenbach, D.: Atmospheric year-round records of dicarboxylic acids and sulfate at three French sites located between 630 and 4360 m elevation, J. Geophys. Res., 110, D13302, doi:10.1029/2004JD005515, 2005.

Lelieveld, J. and Crutzen, P. J.: The role of clouds in tropospheric photochemistry, J. Atmos. Chem., 12, 229-267, 1991.

Leriche, M., Chaumerliac, N., and Monod, A.: Coupling quasispectral microphysics with multiphase chemistry: a case study of a polluted air mass at the top of the Puy de Dôme mountain (France), Atmos. Environ., 35, 5411-5423, 2001.

Leriche, M., Curier, R., Deguillaume, L., Caro, D., Sellegri, K., and Chaumerliac, N.: Numerical quantification of sources and phase partitioning of chemical species in cloud: application to wintertime anthropogenic air masses at the Puy de Dôme station, J. Atmos. Chem., 57, 281-297, 2007.

Lim, Y. B., Tan, Y., Perri, M. J., Seitzinger, S. P., and Turpin, B. J.: Aqueous chemistry and its role in secondary organic aerosol (SOA) formation, Atmos. Chem. Phys., 10, 1052110539, doi:10.5194/acp-10-10521-2010, 2010.

Löflund, M., Kasper-Giebl, A., Schuster, B., Giebl, H., Hitzenberger, R., and Puxbaum, H.: Formic, acetic, oxalic, malonic and succinic acid concentrations and their contribution to organic carbon in cloud water, Atmos. Environ., 36, 1553-1558, 2002.

Lurmann, F. W., Lloyd, A. C., and Atkinson, R.: A chemical mechanism for use in long-range transport/acid deposition computer modeling, J. Geophys. Res., 91, 1905-1936, 1986.

Mack, J. and Bolton, J. R.: Photochemistry of nitrite and nitrate in aqueous solution: a review, J. Photochem. Photobiol., A, 128, $1-13,1999$.

Madronich, S. and Calvert, J. G.: Permutation Reactions of Organic Peroxy Radicals in the Troposphere, J. Geophys. Res., 95, 56975715,1990 .

Marinoni, A., Laj, P., Sellegri, K., and Mailhot, G.: Cloud chemistry at the Puy de Dôme: variability and relationships with environmental factors, Atmos. Chem. Phys., 4, 715-728, doi:10.5194/acp-4-715-2004, 2004.

Marinoni, A., Parazols, M., Brigante, M., Deguillaume, L., Amato, P., Delort, A.-M., Laj, P., and Mailhot, G.: Hydrogen peroxide in natural cloud water: Sources and photoreactivity, Atmos. Res., 101, 256-263, 2011.

Matthias-Maser, S. and Jaenicke, R.: The size distribution of primary biological aerosol particles with radii $>0.2 \mu \mathrm{m}$ in an urban/rural influenced region, Atmos. Res., 39, 279-286, 1995.

Matthias-Maser, S., Bogs, B., and Jaenicke, R.: The size distribution of primary biological aerosol particles in cloud water on the mountain Kleiner Feldberg/Taunus (FRG), Atmos. Res., 54, 113, 2000.

Monod, A. and Carlier, P.: Impact of clouds on the tropospheric ozone budget: Direct effect of multiphase photochemistry of soluble organic compounds, Atmos. Environ., 33, 4431-4446, 1999.
Ravishankara, A. R.: Heterogeneous and Multiphase Chemistry in the Troposphere, Science, 276, 1058-1065, doi:10.1126/science.276.5315.1058, 1997.

Reasoner, D. J. and Geldreich, E. E.: A new medium for the enumeration and subculture of bacteria from potable water, Appl. Environ. Microbiol., 49, 1-7, 1985.

Sahin, N.: Oxalotrophic bacteria, Res. Microbiol., 154, 399-407, 2003.

Sattler, B., Puxbaum, H., and Psenner, R.: Bacterial growth in supercooled cloud droplets, Geophys. Res. Lett., 28, 239-242, 2001.

Saxena, P. and Hildemann, L. M.: Water-soluble organics in atmospheric particles: A critical review of the literature and application of thermodynamics to identify candidate compounds, J. Atmos. Chem., 24, 57-109, 1996.

Sellegri, K., Laj, P., Marinoni, A., Dupuy, R., Legrand, M., and Preunkert, S.: Contribution of gaseous and particulate species to droplet solute composition at the Puy de Dôme, France, Atmos. Chem. Phys., 3, 1509-1522, doi:10.5194/acp-3-1509-2003, 2003.

Sempéré, R. and Kawamura, K.: Comparative distributions of dicarboxylic acids and related polar compounds in snow, rain and aerosols from urban atmosphere, Atmos. Environ., 28, 449-459, 1994.

Sun, Y. L., Zhang, Q., Anastasio, C., and Sun, J.: Insights into secondary organic aerosol formed via aqueous-phase reactions of phenolic compounds based on high resolution mass spectrometry, Atmos. Chem. Phys., 10, 4809-4822, doi:10.5194/acp-104809-2010, 2010.

Tan, Y., Carlton, A. G., Seitzinger, S. P., and Turpin, B. J.: SOA from methylglyoxal in clouds and wet aerosols: Measurement and prediction of key products, Atmos. Environ., 44, 5218-5226, 2010.

Tilgner, A. and Herrmann, H.: Radical-driven carbonyl-to-acid conversion and acid degradation in tropospheric aqueous systems studied by CAPRAM, Atmos. Environ., 44, 5415-5422, doi:10.1016/j.atmosenv.2010.07.050, 2010.

Vaïtilingom, M., Amato, P., Sancelme, M., Laj, P., Leriche, M., and Delort, A.-M.: Contribution of microbial activity to carbon chemistry in clouds, Appl. Environ. Microbiol., 76, 23-29, doi:10.1128/aem.01127-09, 2010.

Warneck, P.: In-cloud chemistry opens pathway to the formation of oxalic acid in the marine atmosphere, Atmos. Environ., 37, 2423-2427, 2003.

Winiwarter, W., Fierlinger, H., Puxbaum, H., Facchini, M. C., Arends, B. G., Fuzzi, S., Schell, D., Kaminski, U., Pahl, S., Schneider, T., Berner, A., Solly, I., and Kruisz, C.: Henry's law and the behavior of weak acids and bases in fog and cloud, J. Atmos. Chem., 19, 173-188, 1994.

Wolke, R., Sehili, A. M., Simmel, M., Knoth, O., Tilgner, A., and Herrmann, H.: SPACCIM: A parcel model with detailed microphysics and complex multiphase chemistry, Atmos. Environ., 39, 4375-4388, 2005. 